\title{
Assessment of Aerosol Optical Depth over Indian Subcontinent during COVID-19 lockdown (March-May 2020)
}

\author{
Krushna Chandra Gouda • Iranna Gogeri • \\ Aruna Singanahalli ThippaReddy
}

Received: 9 October 2021 / Accepted: 5 February 2022 / Published online: 17 February 2022

(C) The Author(s), under exclusive licence to Springer Nature Switzerland AG 2022

\begin{abstract}
The COVID-19 pandemic has created a major threat to human beings and huge losses over the globe. In order to control the pandemic spread, almost all parts of the world imposed lockdown. The imposed lockdown drastically impacted on reduction in the atmospheric pollutions and also resulted in net decrease in aerosol optical depth (AOD) in the atmosphere. In this study, the reduction in the AOD during the COVID-19 lockdown over the Indian subcontinent is being assessed using the moderate resolution imaging spectroradiometer (MODIS) satellite data available in Giovanni version 4.34 developed by NASA. The long-term mean analysis is computed considering 20 years (i.e., 2000-2019) data on Terra platform with a temporal resolution of daily and monthly and spatial resolution of 1 degree. The dataset of AOD with a temporal resolution of monthly was used for investigation of AOD anomaly for March, April and May 2020, and the seasonal variation (March to May 2020) is also assessed. Similarly, the daily scale
\end{abstract}

K. C. Gouda $(\bowtie) \cdot$ I. Gogeri

CSIR - Fourth Paradigm Institute, Wind Tunnel Road,

Bangalore-560037, India

e-mail:kcgouda@csir4pi.in

K. C. Gouda · I. Gogeri · A. S. ThippaReddy

Academy of Scientific and Innovative Research (AcSIR),

Uttar Pradesh, Ghaziabad 201002, India

A. S. ThippaReddy

Surface Engineering Division, CSIR - National Aerospace

Laboratories, HAL Airport Road, Bangalore-560017, India dataset was used to investigate the percentage change in AOD during pre-lockdown and lockdown period with respect to long-term mean. The key findings in the present study show that reduction in AOD level over Indian subcontinent is approximately $14.75 \%$ during the lockdown period with spatial variation in the magnitude from region to region. The level of AOD is greatly reduced in the northern part of India $(\sim 22.53 \%)$, whereas changes in the southern part of India are much less $(\sim-0.31 \%)$; this may be due to ongoing anthropogenic activities during the lockdown period in this region. Furthermore, a positive AOD anomaly was observed in the eastern and central regions of India (i.e., over the states of Odisha, Chhattisgarh, Telangana, Jharkhand, West Bengal, Part of Maharashtra and Karnataka). However, negative AOD anomaly was observed in the north and northwest regions of India, whereas not much change in the AOD anomaly in other parts of the country. The overall assessment of the AOD level shows a net decrease over the Indian subcontinent during the lockdown period, i.e., March to May 2020. This kind of assessment study will surely help the government for the sustainable policy decisions for atmospheric pollution control by implementing proper lockdown procedures over various parts of the country.

Keywords MODIS - Aerosol - SARS-CoV-2 . India $\cdot$ Pollution $\cdot$ Summer 


\section{Introduction}

The COVID-19 virus critically ruined the whole world by spreading human to human and created huge economical losses to the entire globe (Bukhari \& Jameel, 2020). The WHO office in China reported the first case of SARS-CoV-2 in Wuhan City, Hubei Province of China in December 2019 (Shi et al., 2020). Within a month, several people got affected by this virus due to its rapidly transmitting in nature. The virus was rapidly spreading across the globe with more number of confirmed cases including several deaths in all parts of the world. The global situation of COVID-19 cases can be seen in the WHO Corona virus (COVID-19) Dashboard. The whole world went to lockdown declaring this as a pandemic by World Health Organization (WHO, 2020) during March to May 2020.

The first confirmed case was reported in India from Kerala state during January 2020 (Gautam, 2020), and since then, cases got rapidly increasing in other parts of India. This forced the Indian government to enforce lockdown across the country to control spreading of COVID-19 virus. The lockdown got enforced in 4 phases, which was announced by the prime minister of India, initial nationwide lockdown started from 25 March 2020 to 14 April 2020, second phase lockdown from 15 April to 3 May 2020, third phase was from 4 to 17 May 2020, and fourth phase was from 18 to 31 May 2020. The lockdown witnessed a complete shutdown of the vehicular movements, flights, railways, industrial activities, public gatherings, markets as well as academic institutions resulting in no movement of people also outside their residence. The outcome of lockdown resulted in controlled positive COVID-19 cases and mortality rate significantly in various parts of India. Many researchers and scientist have put their efforts to study the impact of lockdown on the atmosphere apart from research in the medical field (Kanniah et al., 2020; Nakada \& Urban, 2020; Suresh et al., 2020) over different regions of the world such as Europe (Tobias et al., 2020), north and southAmerica (Zalakeviciute et al., 2020), South-Asia (Li \& Tartarini, 2020; Navinya et al., 2020) and middleeast (Sahin, 2020; Faridi et al., 2020), and all these studies reported the improvement in air quality during the lockdown period because of reduction in anthropogenic activities including industry and vehicle restriction. The results of the lockdown also reported a decrease in ambient particulate matter (PM2.5 and PM10), nitrogen dioxide $\left(\mathrm{NO}_{2}\right)$, carbon monoxide (CO), sulfur dioxide $\left(\mathrm{SO}_{2}\right)$, carbon monoxide $(\mathrm{CO})$ and aerosol concentrations over East China, Southern China, Spain, Western Europe, Australia, South Korea, Italy and Western China as compared to prelockdown periods (Baldasano, 2020; Filonchyk et al., 2020; Liu et al., 2020; Menut et al., 2020; Wan et al., 2020; Zhang et al., 2020). As a consequence of the lockdown, the regions witnessed low vehicular emissions, Particulate matter emissions, Greenhouse gas emissions, aerosols concentrations; thus, improvement in the air quality has been observed because of the reduction in the anthropogenic activities (Zambranomonserrate et al., 2020; Sharma et al., 2020).

Satellite-derived dataset is a cost-effective method to study effects over the long-term variation. Aerosol measurements through satellite remote sensing have been established since the late 1970s. However, the limitation was in the restriction of detection of properties of aerosol over the ocean till the development of the Total Ozone Mapping Spectrometer (TOMS), which has the capability to detect aerosols over both land and ocean (Herman et al., 1997; Hsu et al., 1996). In recent years, MODIS-based Terra and Aqua satellites platform has emerged as a systematic approach for retrieving the aerosol properties. The dataset is being made available throughout the year for selected regions with fewer data gaps. Hence, this MODIS platform enables the researchers to use aerosol optical properties (Kinget al., 1999). MODIS satellite data provide useful information about global air pollution and thus provide new insights into the distribution of the air pollutants in the atmosphere. The capability of MODIS platform for monitoring global and local air pollution has been demonstrated with considerably better accuracy and spatial sensitivity in the earlier studies (Chu et al., 2003; King et al., 1999).

Aerosols, mainly referred as particulate matter, are basically obtained from anthropogenic or natural emission sources, and these have adverse effects on atmospheric pollution and human health (Al-Kindi et al., 2020; Burnett et al., 2018; Cohen et al., 2017; Lave \& Seskin, 1970; Pope et al., 2009, 2020) . There is evidence of the relation of fine particulate matter, aerosol driven air pollution and the diseases like lung cancer, cardiovascular mortality and life expectancy also (Pope et al., 2004, 2009, 2020; Al-Kindi 
et al., 2020). So, AOD is a critical topic in the global environmental science community (Pöschl, 2005). Aerosols have direct and indirect effects on climate change by scattering-absorbing solar radiations and altering cloud properties, respectively (Sehwartz et al., 1995). Anthropogenic aerosols and their radiative forces are responsible for changing land surface temperature by restricting effect of greenhouse gases over the regions, thus creating uncertainty in the climate prediction. Especially they have an adverse effect on vegetation by decreasing sunlight due to its loading; hence, the effect of AOD level cannot be neglected at all (Houghton et al., 1994; Russell et al., 1999; Kaufman et al., 2002; Satheesh et al., 2000). Rainfall distribution is also affected by AOD distribution as it controls the cloud formation during the pre-monsoon season in Indian subcontinent and thus disturbs the hydrological cycle (Ramanathan et al., 2001a). Hence, effect of AOD level with the climate parameters especially with cloud formation, rainfall, the influence of dust storms, temperature, humidity and vegetation needs attention of the researchers. Problems associated due to AOD level in the atmosphere need to be addressed in line with various previous studies (Liao et al., 1998; King et al., 2003; Dey et al., 2004; Ramanathan et al., 2001b; Rotstayn et al., 2000). In India major accumulation of aerosols observed to be over the Ganga basin, it may be because of desert dust and industrial pollution. This AOD level over the Ganga basin will further have an impact on monsoon rainfall distribution over this region (Chinnam et al., 2006; Gautam et al., 2010; Giles et al., 2011; Srivastava et al., 2012). Various studies have shown impact of AOD on climate change over various regions of the world. Also, aerosol causes adverse effects on human health such as lungs-related issues, asthma and pulmonary inflammation (Huang et al., 2012; Mulenga et al., 2019). Also as the SARS COVID-19 is an influenza-related virus disease so the assessment of the AOD will definitely help the researchers in better understanding the viral dynamics.4

All the studies performed previously were concentrated on various regions of the world. Extraction of AOD data with a temporal resolution of daily and spatial resolution of 1 degree from MODIS terra platform in GIOVANNI and processing of these data for a long term of 20 years is a key aspect in this study. This study also emphasizes variation of AOD level over Indian subcontinent focusing on southern and northern parts of India during lockdown period with respect to pre-lockdown periods.

Thus, the effect of anthropogenic activities on climate change during lockdown phases can be well understood by studying the variation of AOD level in atmosphere. The present study therefore assesses AOD levels over the Indian subcontinental during imposed lockdown periods due to COVID-19. The overall objectives of this study are: (a) to analyze the aerosol levels over the Indian subcontinent with special focus on the southern and northern parts of India separately and (b) to evaluate the AOD anomaly during imposed lockdown phases with respect to longterm mean.

\section{Data and methodology}

The satellite MODIS data are being collected from the Giovanni online data system, developed and maintained by the NASA GES DISC. The data lineage can be easily retrieved using Giovanni online data system for geophysical parameters. The dataset files can be downloaded directly in various formats such as netCDF, cvsetc required for further data analysis and plotting. The MODIS datasets were pooled from the Giovanni online data system https://giovanni.gsfc.nasa.gov developed by the NASA GES DISC (Acker \& Leptoukh, 2007), and the sensor details are explained by Li et al. (2020) and the retrieval algorithms are discussed in earlier works (Hsu et al., 2019 and Sayer et al., 2019). The AOD at $550 \mathrm{~nm}$ is utilized in this study as this product has better consistency (Lyapustin \& Wang, 2018). In the present study, assessment of AOD anomaly was performed using the dataset of AOD at $550 \mathrm{~nm}$ obtained from MODIS-based Terra platform [MODIS-Terra MOD08_ M3 v6.1] for the summer season, i.e., in the months of March, April and May (2000-2020) over Indian region. The monthly average of AOD level on land considered for investigating AOD variation on Indian land region, combined land and ocean data for investigating AOD variation on the ocean surrounded by Indian region. Furthermore time series, area-averaged of AOD $550 \mathrm{~nm}$ (Deep Blue, Land-only) also computed.

Twenty years of the AOD data (2000-2019) are analyzed in this study to understand the long-term variation of AOD in India. The region of interest in the present study is the Indian subcontinent $\left(62^{\circ} \mathrm{E}-96^{\circ} \mathrm{E}, 8^{\circ} \mathrm{N}-36^{\circ} \mathrm{N}\right)$. The data resolution is obtained by high-resolution raster 
array with considering proportional weights to shape coverage in all cells. To minimize the influence of lower shape coverage on results of area average mean, the cosine of latitude is considered for weights corresponding to shape coverage. Shapes corresponding to the ocean were masked while retrieving dataset for the land region by regrinding the algorithms. The data are being passed through a quality control algorithm.

In this work, the daily changes in the AOD averaged over regions like all India, North India and South India by considering the anomaly of the day in 2020 with respect to the 20-year long-term mean values [AOD_LTM (i)] for the corresponding day have been computed.

$$
\begin{aligned}
& A O D \_A N O M A L Y(\text { day }, 2020) \\
& =\frac{A O D(\text { day }, 2020)-A O D \_L T M(\text { day })}{A O D \_L T M(\text { day })} \times 100
\end{aligned}
$$

where

$$
A O D \_L T M(\text { day })=\frac{1}{20} \sum_{\text {year }=2000}^{2019} A O D(\text { day, year })
$$

is the long-term mean value for a particular day.

Similarly, the monthly anomaly of AOD (AOD_ Monthly_ANOMALY (month, 2020) during 2020 March, April, May and seasonal, i.e., March-May 20,202 with respect to 20-year long-term mean $A O D_{\text {monthly }} \operatorname{LTM}(m)$ also computed at latitude $j$ and longitude $i$.

AOD_Monthly_ANOMALY $(i, j$, month, 2020)

$$
=\frac{A O D_{\text {monthly }}(i, j, m, 2020)-A O D_{\text {monthly }} \operatorname{LTM}(i, j, m)}{A O D_{\text {monthly }} \operatorname{LTM}(i, j, m)} \times 100
$$

where

$$
A O D_{\text {monthly }} \operatorname{LTM}(i, j, m)=\frac{1}{20} \sum_{\text {year }=2000}^{2019} A O D_{\text {monthly }}(i, j, m, \text { year })
$$

is the long-term mean value for a particular month $m$ at latitude $j$ and longitude $i$.

To assess the amount of AOD during whole lockdown period of 10 weeks, the 10-week averaged AOD is compared with the AOD averaged over previous 10 weeks during pre-lockdown period and the total change in AOD is computed using the following algorithm

$$
A O D_{\text {Change }}=\frac{A O D(\text { lockdown })-A O D(\text { Prelockdown })}{A O D(\text { Prelockdown })} \times 100
$$

where $A O D($ lockdown $)$ and $A O D($ Prelockdown) are the average values of AOD during 10 weeks of lockdown and 10 weeks of pre-lockdown period.

The dataset retrieved from the MODIS platform is further used to investigate the variation of AOD level over the Indian subcontinent region in the spatiotemporal domain during pre-lockdown and lockdown period. The monthly average of AOD level was computed for March, April and May, and the seasonal average value is computed using the 20 years of data. Then, anomaly for the 2020 year is computed using the average value and the 2020 values for all the three months and summer season as a whole. The anomaly in AOD during 2020 is expressed as \% change with respect to the long-term mean.

\section{Results and discussion}

The multi-scale analysis of AOD distribution at daily, weekly and monthly time scales is discussed along with the spatial anomaly of during the COVID-19 lockdown in 2020 summer season in this section.

\section{Time series analysis of AOD level across India}

The time series analysis of all India averaged AOD anomaly from 01 Jan to 31 Dec 2020 normalized with respect to long-term mean is presented in Fig. 1. The changes in AOD level normalized to long-term mean across whole India are presented in Fig. 1a. The first 60 days of the year corresponding to month of January and February shows AOD normalized values are positive, sometime crosses more than $50 \%$ with respect to long-term mean except very few negative values in between. Similarly, approximately last 70 days of the year corresponding to part of October month, November and December also show positive AOD normalized values, sometimes crossing more than $50 \%$ with respect to long-term mean except very few negative values in between. However, the rest of the days in year 2020 show negative anomaly AOD, sometimes less than $50 \%$ with respect to long-term mean. This shows AOD level has been drastically reduced throughout the year 2020 except few days in the beginning and end of the year. The reduction is mainly due to the lockdown the main sources, i.e., industry and vehicle movement 
(a)

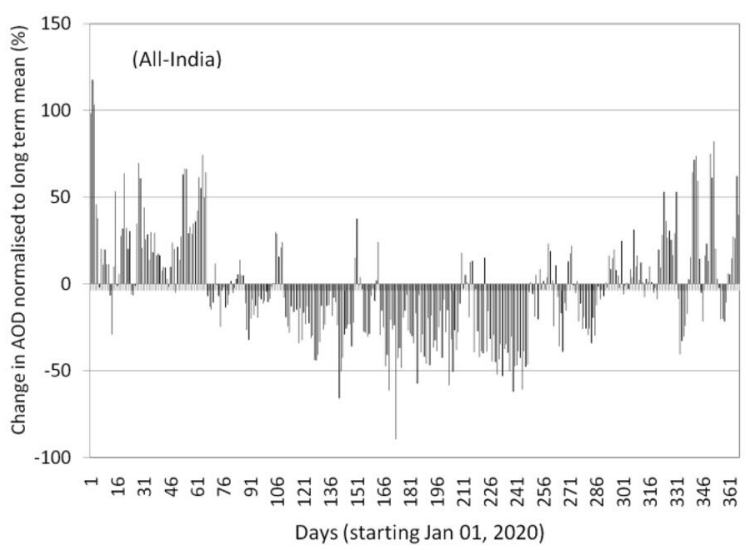

(b)

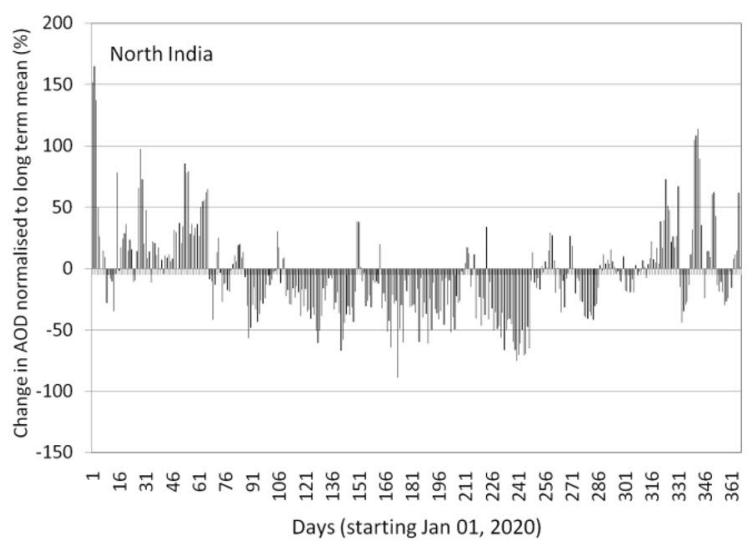

(c)

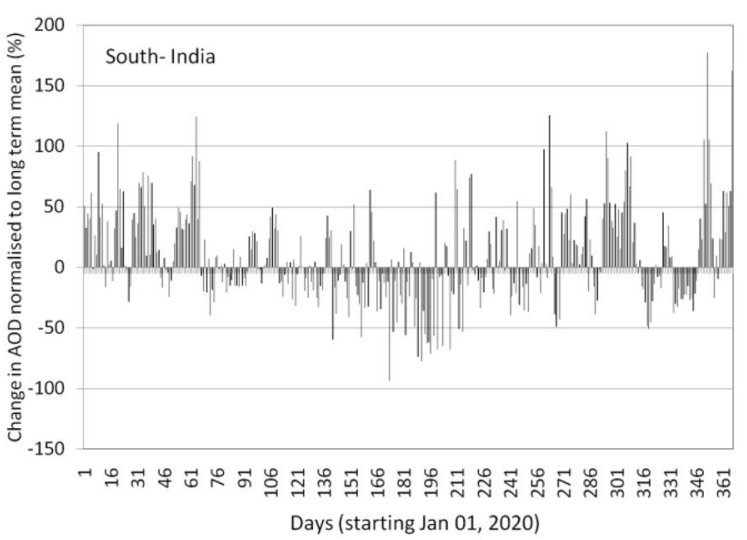

Fig. 1 Variation of daily AOD anomaly during 01 Jan to 31 Dec 2020 over (a) all India, (b) North India and (c) South India. The anomaly is expressed as \% change in the AOD with respect to the long-term mean (20 years) values

were closed throughout the country. This results are consistent with the some other related studies carried out on urban cities (Gouda et al., 2021; Kanniah et al., 2020; Pathakoti et al., 2021). The maximum and minimum values of AOD anomaly (normalized with respect to long-term mean) varied from +117 to $-89 \%$ across the country. The same analysis over North India $\left(62^{\circ} \mathrm{E}-96^{\circ} \mathrm{E}, 8^{\circ} \mathrm{N}-22^{\circ} \mathrm{N}\right)$ shows similar trend of AOD anomaly values with respect to longterm mean as observed in the all India case. The maximum and minimum values of AOD anomaly varied from +164 to $-89 \%$ across North India. The changes in AOD anomaly in 2020 over South India $\left(62^{\circ} \mathrm{E}-96^{\circ} \mathrm{E}\right.$, $22^{\circ} \mathrm{N}-36^{\circ} \mathrm{N}$ ) are presented in Fig. 1c, showing a similar trend of variation. During first 60 days and last 70 days of the year except in few days, negative values were observed. However, in the rest of the period, more number of days shows positive AOD anomaly in the southern part of country. The maximum and minimum values of AOD anomaly varied from +177 to $-93 \%$ across South India.

\section{Weekly variation of AOD level during pre-lockdown and lockdown period}

Weekly variation of AOD level during 01 Jan 2020 to 31 May 2020 over 22 weeks is presented in Fig. 2. The 
(a) All India

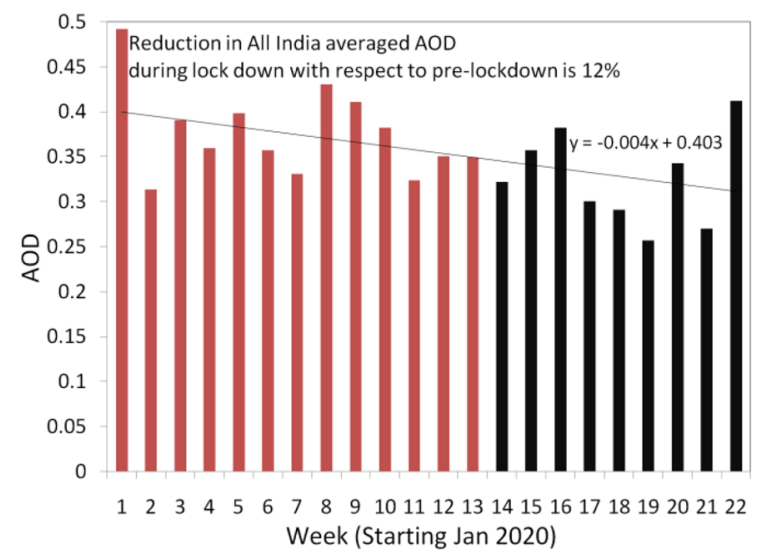

(b) North India

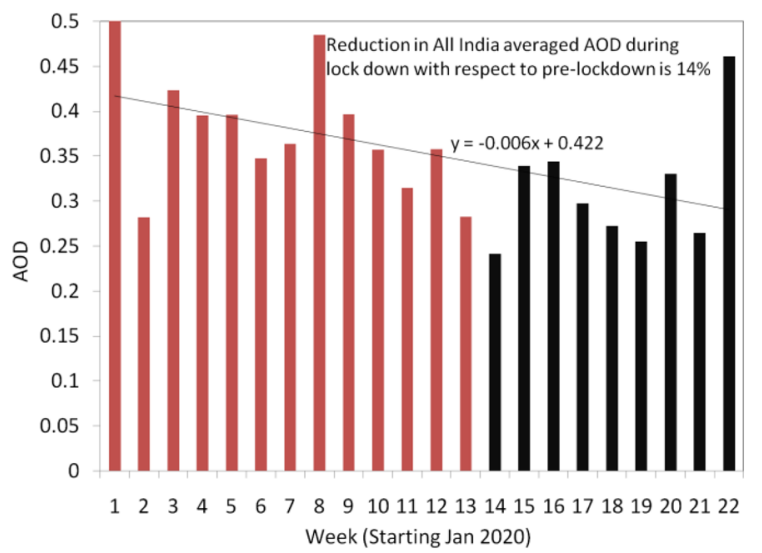

(c) South India

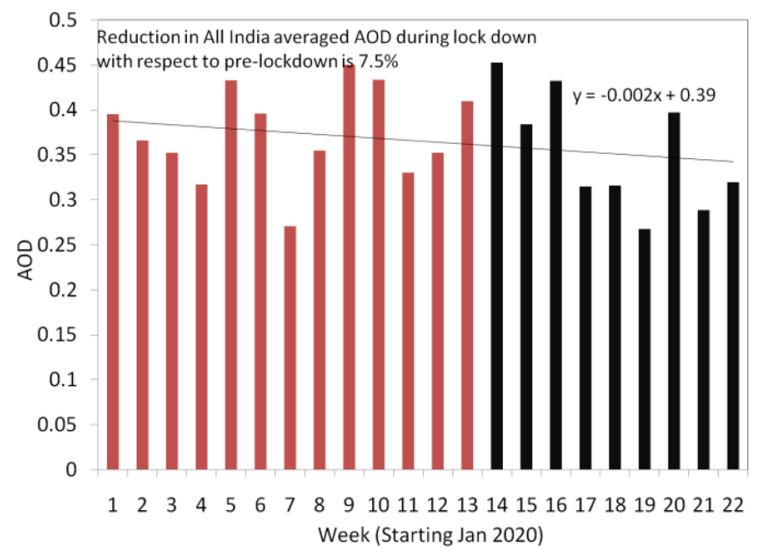

Fig. 2 Weekly variation of AOD during 01 Jan to 31 May 2020 over (a) all India, (b) North India and (c) South India. The \% change in the AOD during 10-week lockdown period (week

AOD level during 10 weeks in the pre-lockdown period is indicated by red color, whereas the AOD level during 10 weeks of lockdown period is indicated by black color in the figure, and it is observed that there is a decreasing trend of AOD level in all the study regions, i.e., all India, North India and South India during this lockdown period. Weekly variation of AOD level in all India during pre-lockdown and lockdown period is presented in Fig. 2a. The analysis clearly indicates a net reduction of $12 \%$ AOD level during lockdown period as compared to pre-lockdown period resulted in all India scale. The same analysis over North (south) India resulted in reduction of $19.5 \%$ (3\%) in the weekly AOD levels as depicted in Fig. 2b, c.
13 to 22 ) with respect to pre-lockdown 10 -week periods (02 to 12 weeks) is computed and mentioned in each panel

\section{Spatial anomaly of AOD during COVID-19 Lockdown in 2020}

The estimation of AOD monthly anomaly is computed to know the spatial variation of AOD across the Indian subcontinent during the lockdown period imposed due to the SARS-CoV-2 pandemic in March-May 2020. As described, earlier 20-year period (2000-2019) data are considered for the long-term mean value computation and the monthly anomaly for the year 2020 is computed with respect to the long-term mean across all India presented in Fig. 3. The analysis clearly indicates AOD level decreased (negative anomaly) during 2020 lockdown period as compared to long-term 
(a) March

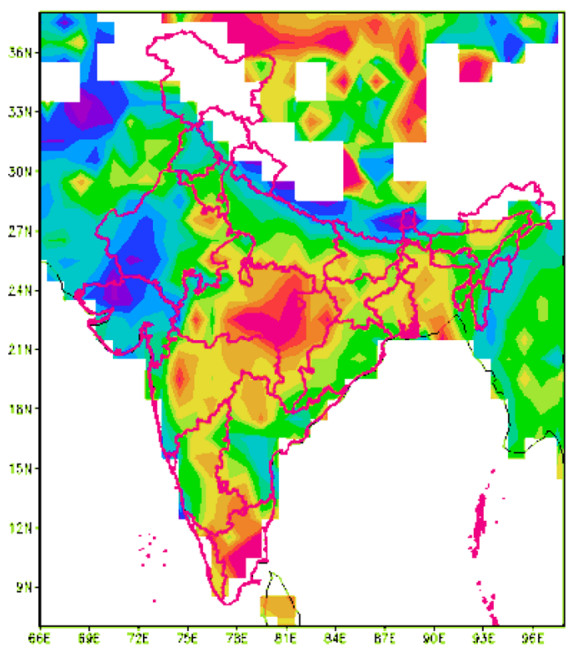

(c) May

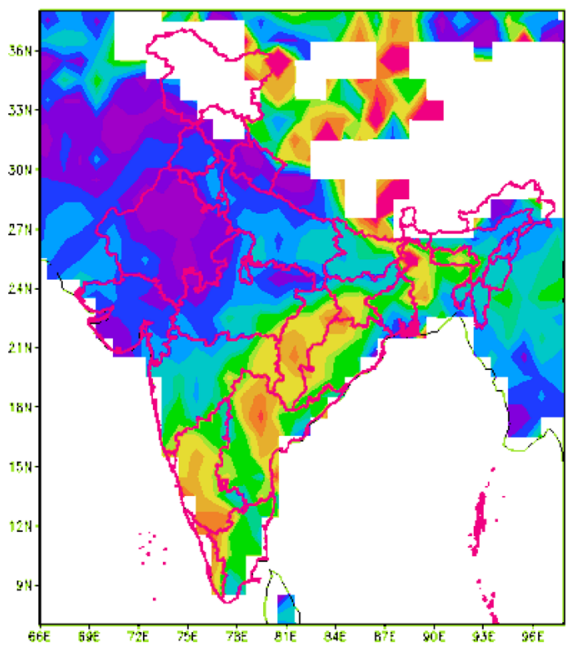

(b) April
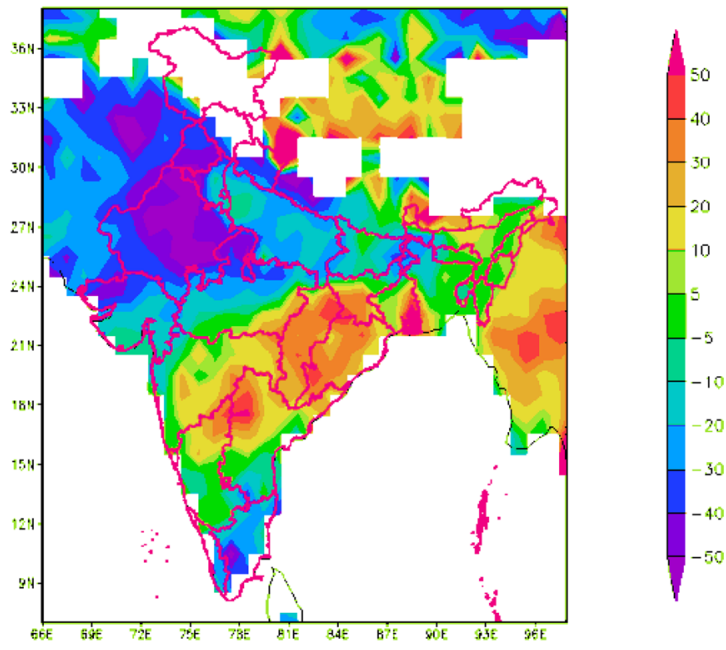
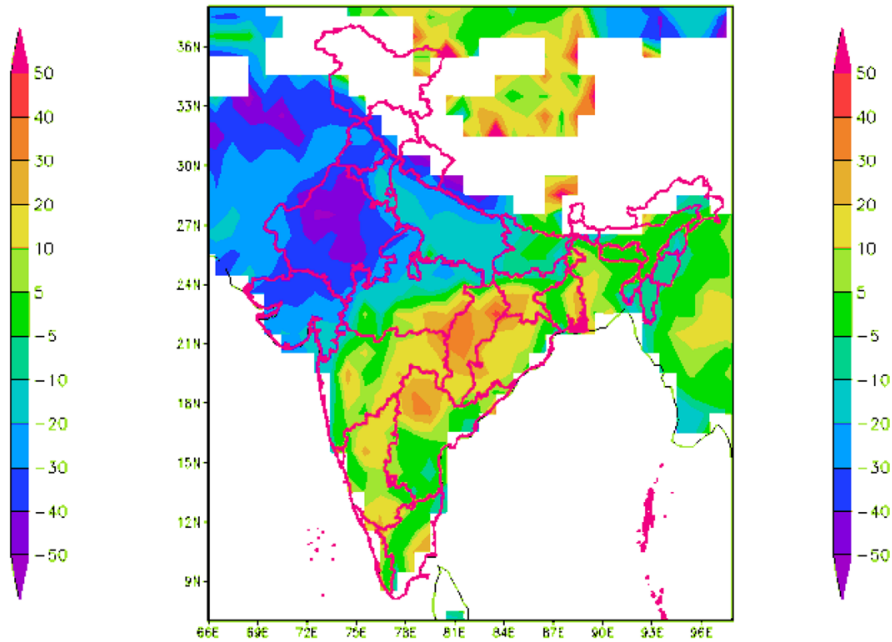

Fig. 3 Monthly AOD anomaly (expressed as \% of long-term mean) during year 2020 over Indian subcontinent for the year 2020 (a) March, (b) April, (c) May and (d) summer [March-May]

mean. The variation AOD anomaly level in the month of March 2020 which represents the phase 1 lockdown (only 10 days) in India shows a reduction in AOD level across the nation except for few states like Madhya Pradesh, Maharashtra and some parts of Telangana, Chhattisgarh, Odisha, Karnataka, Tamilnadu, Rajasthan and West Bengal. During the month of April 2020, when the phase 2 lockdown has been strictly imposed for a whole month, the AOD level has been further reduced with respect to the long-term mean as compared to the level of AOD during the previous month. However, increase in the AOD level was observed across southeastern and northeast states during April 2020 as shown in Fig. 3b. Similarly, during 
Table 1 Change in AOD during different phases of lockdown during summer 2020 over different regions in India. The anomaly expressed as \% change in the AOD in 2020 with respect to 20-year average value is presented. The regions experiencing more than $10 \%$ reduction in AOD are * marked

\begin{tabular}{lllll}
\hline Stages of lockdown & Period & All India & North India & South India \\
\hline Lockdown 1 & March 24-April 14 & -5.97 & $-16.55^{*}$ & 4.28 \\
Lockdown 2 & April 15-May 03 & $-16.32 *$ & $-24.33^{*}$ & 0.46 \\
Lockdown 3 & May 04-May 17 & $-22.57 *$ & $-28.51^{*}$ & -4.10 \\
Lockdown 4 & May 18-May 31 & $-20.41^{*}$ & $-24.88^{*}$ & -5.11 \\
Whole lockdown period & March 24-May 31 & $-14.75^{*}$ & $-22.53^{*}$ & 0.31 \\
\hline
\end{tabular}

month of May 2020 (phase 3 lockdown), there is a significant reduction (negative anomaly) in the AOD level which is observed. This reduction might have also triggered due to the tropical cyclone "Amphan" in the Bay of Bengal as reported in an earlier study (Kumar et al., 2021) along with the lockdown restriction. However, few patches of positive values of AOD anomaly have been observed over the south and southeastern states (Fig. 3c). Moreover, the seasonal (March-May) AOD anomaly across the Indian subcontinent (Fig. 3d) shows a negative AOD anomaly across most of the regions of the country. This indicates AOD level has been decreased during the lockdown period imposed due to the SARS-CoV-2 pandemic as compared to long-term mean. However, few positive anomaly patches were seen in Maharashtra, Madhya Pradesh, Karnataka, Telangana, Chhattisgarh, Odisha and West Bengal which may be due to some transport activities. Similar results are being obtained by few researchers while assessing the AOD and air quality which are fully influenced by the shutdown and lockdown phases in India (Soni, 2021; Sharma et al., 2020; Gautham, 2020; Vasudevan et al., 2021; Satya, 2021).

The percentage change of AOD level during different phases of lockdown period with respect to the long-term mean across various regions of India is summarized in Table 1. It clearly reveals that over All India and North India there was a reduction in AOD content during all the phases of the lockdown period and the reductions were very high in these regions compared to South India. The region-wise analysis also revealed that an adequate reduction in AOD level of $28.51 \%$ in North India and $22.57 \%$ in all India during the third phase of lockdown, i.e., during May 04-17, 2020.

\section{Conclusions}

The SARS-CoV-2 pandemic has created huge losses over the globe and a serious threat to the human beings. However, lockdown imposed due to pandemic has revealed that AOD level was adequately reduced across the Indian Territory; this shows earth can restore by and of itself, if a chance is provided by human beings. The region-wise investigation shows that North India had better influence of the lockdown period, where the AOD level decreased up to $14 \%$ during lockdown period with respect to long-term mean, whereas in South India impact of the lockdown period on AOD level reduction is a little lesser due to reduction was up to $7.5 \%$ only. Furthermore, reduction in all India AOD levels was considerably less during the lockdown period as compared to the pre-lockdown period, where the level of AOD had reduced up to $12 \%$. The AOD anomaly showed negative values across most of the regions in the country except few positive AOD anomaly patches in the southeastern and northeast states. Consequently, imposing lockdown across states or nations for certain duration may play a vital role in reducing air pollution levels. Hence, the government may tactically impose such lockdown events, especially in pollution hotspot zones to improve better air quality. Also, ecologists and policymakers may work out creative methods and plan of action to implement lockdown events in consultation with the government by considering minuscule effect on the country's economy.

Acknowledgements The CSIR 4PI high-performance computing (HPC) facility used for computing is acknowledged gratefully. The authors acknowledge Head, CSIR 4PI, for 
support and encouragement. The authors acknowledge Giovanni, NASA, for providing the data used in this study.

Authors' contributions The study was conceptualized by Krushna; study design, analysis of data and preparation of the manuscript were done by Krushna, Iranna and Aruna.

Funding This work is supported by the projects funded by the Department of Science and Technology under Epidemiology Data Analytics (EDA) of Interdisciplinary cyber physical systems (ICPS) programme (Grant number: DST/ICPS/ EDA/2018), Govt. of India, and DST-RFBR project on "Analysis of urban heat islands, air pollution dynamics, and extreme weather phenomena in India and Russia" (Grant number INT/ RUS/RFBR/P-336 2019) Govt. of India and another project funded under National Mission on Himalayan Studies (NMHS) of Ministry of Environment, forest and climate change, Govt. of India (grant no: GBPNI/NMHS-2019-20/MG/315).

Availability of data and materials Data are openly available in public repository.

\section{Declarations}

Ethics approval Not applicable.

\section{Consent for publication Not applicable.}

Conflict of interest The authors declare that there is no conflict of interests.

\section{References}

Al-Kindi, S. G., Brook, R. D., Biswal, S., \& Rajagopalan, S. (2020). Environmental determinants of cardiovascular disease: Lessons learned from air pollution. Nature Reviews. Cardiology, 17, 656-672.

Acker, J. G., \& G. Leptoukh G,. (2007). Online Analysis Enhances Use of NASA Earth Science Data, Eos. Trans. $A G U ., 88(2), 14-17$.

Baldasano, J. M. (2020). Covid-19 lockdown effects on air quality by $\mathrm{NO} 2$ in the cities of Barcelona and Madrid (Spain). Science of the Total Environment, 741:140353. https://doi.org/10.1016/j.scitotenv.2020.140353

Bukhari, Q., \& Jameel, Y. (2020). Will corona virus pandemic diminish by summer? SSRN Electron. J. https://doi.org/ 10.2139/ssrn.3556998

Burnett, R., et al. (2018). Global estimates of mortality associated with long-term exposure to outdoor fine particulate matter. Proceedings of the National Academy of Sciences of the United States of America, 115, 9592.

Chinnam, N., Dey, S., Tripathi, S. N., \& Sharma, M. (2006). Dust events in Kanpur, northern India: Chemical evidence for source and implications to radiative forcing. Geophysical Research Letters, 33, L08803. https://doi.org/10.1029/ 2005GL025278
Chu, D. A., Kaufman, Y. J., Zibordi, G., Chern, J. D., Mao, J., Li, C., \& Holben, B. N. (2003). Global Monitoring of Air Pollution over Land from EOS-Terra MODIS. Journal of Geophysical Research, 108(D21), 4661. https://doi.org/ 10.1029/2002JD003179

Cohen, A. J., et al. (2017). Estimates and 25-year trends of the global burden of disease attributable to ambient air pollution: An analysis of data from the Global Burden of Diseases Study 2015. Lancet, 389, 1907-1918.

Dey, S., Tripathi, S. N., Singh, R. P., \& Holben, B. N. (2004). Influence of dust storms on the aerosol optical properties over the Indo-Gangetic basin. Journal of Geophysical Research, 109(D20), D20211. https://doi.org/10.1029/ 2004JD004924

Faridi, S., Yousefian, F., Niazi, S., Ghalhari, M. R., Hassanvand, M. S., \& Naddafi, K. (2020). Impact of SARS-CoV-2 on ambient air particulate matter in Tehran. Aerosol Air Qual. Res., 20, 1805-1811. https://doi.org/10.4209/aaqr.2020.05. 0225

Filonchyk, M., Hurynovich, V., Yan, H., Gusev, A., \& Shpilevskaya, N. (2020). Impact assessment of COVID-19 on variations of SO2, NO2, CO and AOD over east China. Aerosol Air Qual. Res., 20, 1530-1540. https://doi.org/10.4209/aaqr.2020.05. 0226

Gautam, R., Hsu, N. C., Lau, K. M. (2010). Pre-monsoon aerosol characterization and radiative effects over the IndoGangetic Plains: Implications for regional climate warming. Journal Geophysical Research, 115: D17208.https:// doi.org/10.1029/2010JD013819

Gautam, S. (2020). The influence of COVID-19 on air quality in India: A boon or inutile. Bulletin of Environment Contamination and Toxicology, 104(6), 724-726. https://doi. org/10.1007/s00128-020-02877-y

Giles, D. M., Holben, B. N., Tripathi, S. N., Eck, T. F., Newcomb, W. W., Slutsker, I., \& Schafer, J. S. (2011). Aerosol properties over the Indo-Gangetic Plain: A mesoscale perspective from the TIGERZ experiment. Journal Geophysical Research, 116: D18203.https://doi.org/10.1029/2011JD015809

Gouda, K. C., Singh, P., P, N., et al. (2021). Assessment of air pollution status during COVID-19 lockdown (MarchMay 2020) over Bangalore City in India. Environmental Monitoring and Assessment, 193, 395. https://doi.org/10. 1007/s10661-021-09177-w

Herman, J. R., Bhartia, P. K., Torres, O., Hsu, C., Seftor, C., \& Celarier, E. (1997). Global distribution of UV-absorbing aerosols from Nim-bus-7/TOMS data, J. Geophys. Res. 102:16,911 - 16,922.

Houghton, J. T., Meira Filho, L. G., Bruce, J., Hoesung, L., Callander, B. A., Haites, E., Harris, N., Maskell, K. (eds) (1995). Climate Change, 1994: Radiative Forcing of Climate Change and an Evaluation of the IPCC IS92 Emission Scenarios (Cambridge Univ. Press, Cambridge, 1995).

Hsu, N. C., Herman, J. R., Bhartia, P. K., Seftor, C. J., Torres, O., Thompson, A. M., Gleason, J. F., Eck, T. F., \& Holben, B. N. (1996). Detection of biomass burning smoke from TOMS measurements. Geophysical Research Letters, 23, $745-748$.

Hsu, N. C., Lee, J., Sayer, A. M., Kim, W., Bettenhausen, C., \& Tsay, S. C. (2019). VIIRS Deep Blue Aerosol Products Over Land: Extending the EOS long-Term Aerosol Data 
Records. Journal of the Geological Society Australia, 124, 4026-4053. https://doi.org/10.1029/2018JD029688

Huang W, Cao J, Tao Y, Dai L, Lu SE, Hou B, Wang Z, Zhu T (2012) Seasonal variation of chemical species associated with short-term mortality effects of PM2.5 in Xi'an, a central city in China. Am. J. Epidemiol. 175 (6):556-566. https://doi.org/10.1093/aje/kwr342

Kanniah, K. D., Zaman, N. A. F. K., Kaskaoutis, D. G., \& Latif, M. T. (2020). Covid-19's impact on the atmospheric environment in the Southeast Asia region. Science of the Total Environment, 736, 139658. https://doi.org/10.1016/j. scitotenv.2020.139658

Kaufman, Y. J., Tanré, D., \& Boucher, O. (2002). A satellite view of aerosols in the climate system. Nature, 419, 215-223.

King, M. D., Kaufman, Y. J., \& Tanre’ D, Nakajima T,. (1999). Remote sensing oftropospheric aerosols from space: Past, present and future. Bull. Meteorol. Soc., 80, 2229-2259.

King, M. D., Menzel, W. P., Kaufman, Y. J., Tanré, D., Gao, B. C., Platnick, S., Ackerman, S. A., Remer, L. A., Pincus, R., \& Hubanks, P. A. (2003). Cloud and Aerosol Properties, Precipitable Water, and Profiles of Temperature and Humidity from MODIS. IEEE Transactions on Geoscience and Remote Sensing, 41, 442-458.

Kumar, S., Lal, P., \& Kumar, A. (2021). Influence of Super Cyclone "Amphan" in the Indian Subcontinent amid COVID-19 Pandemic. Remote Sens Earth Syst Sci, 4, 96-103. https://doi.org/10.1007/s41976-021-00048-z

Lave, L. B., \& Seskin, E. P. (1970). Air pollution and human health. Science, 169, 723-733.

Li, R., Mei, X., Chen, L., Wang, L., Wang, Z., Jing, Y. (2020.) Long-Term (2005-2017) View of Atmospheric Pollutants in Central China Using Multiple Satellite Observations, Remote Sens.-Basel. 12:1041, https://doi.org/10.3390/ rs12061041, 2020.

Li, J., \& Tartarini, F. (2020). Changes in air quality during the COVID-19 Lockdown in Singapore and associations with human mobility trends. Aerosol Air Qual. Res., 20, 17481758. https://doi.org/10.4209/aaqr.2020.06.0303

Liao, H., \& Seinfeld, J. H. (1998). Effect of clouds on direct aerosol radiative forcing of climate. Journal of Geophysical Research, 103, 3781-3788.

Liu, Y., Lin, X., Qin, S. (2020). The short-term seasonal analyses between atmospheric environment and covid-19 in epidemic areas of cities in Australia, South Korea, and Italy.arXiv preprint arXiv:2005.12264.

Lyapustin, A., Wang, Y. (2018). MODIS Multi-angle Implementation of Atmospheric Correction (MAIAC) data user's guide, collection 6 (ver. of June 2018).

Menut, L., Bessagnet, B., Siour, G., Mailler, S., Pennel, R., \& Cholakian, A. (2020). Impact of lockdown measures to combat covid-19 on air quality over Western Europe. Science of the Total Environment, 741, 140426. https://doi. org/10.1016/j.scitotenv.2020.140426

Mulenga, D., Siziya, S. (2019). Indoor Air Pollution Related Respiratory Ill Health, a Sequel of Biomass Use.SciMedicine Journal 1: p. 8 (1). https://doi.org/10.28991/SciMedJ-2019-0101-5

Nakada, L. Y. K., \& Urban, R. C. (2020). Covid-19 pandemic: Impacts on the air quality during the partial lockdown in São Paulo state. Brazil. Science of the Total Environment, 730, 139087. https://doi.org/10.1016/j.scitotenv.2020.139087
Navinya, C., Patidar, G., \& Phuleria, H. C. (2020). Examining effects of the COVID-19 national lockdown on ambient air quality across urban India. Aerosol Air Qual. Res., 20, 1759-1771. https://doi.org/10.4209/aaqr.2020.05.0256

Pathakoti, M., Muppalla, A., Hazra, S., Mahalakshmi, D. V., Sagar, K. K. V., Shekhar, R., et al. (2021). Measurement Report: An Assessment of the Impact of a Nationwide Lockdown on Air Pollution - a Remote Sensing Perspective over India. Atmospheric Chemistry and Physics, 21, 9047-9064. https://doi.org/10.5194/acp-21-9047-2021

Pope, C. A., III., Burnett, R. T., Thurston, G. D., et al. (2004). Cardiovascular mortality and long-term exposure to particulate air pollution: Epidemiological evidence of general pathophysiological pathways of disease. Circulation, 109, 71-77.

Pope, C. A., Ezzati, M., \& Dockery, D. W. (2009). Fine particulate air pollution and life expectancy in the United States, New England. Journal of Medicine, 360, 376-386.

Pope, C. A., III., Burnett, R. T., Thun, M. J., et al. (2020). Lung cancer, cardiopulmonary mortality, and long-term exposure to fine particulate air pollution. JAMA, 287, 1132-1141.

Pöschl, U. (2005). Atmospheric aerosols: Composition, transformation, climate and health effects. Angewandte Chemie International Edition, 44, 7520-7540.

Ramanathan, V., Crutzen, P. J., Kiehl, J. T., \& Rosenfeld, D. (2001a). Aerosols, climate, and the hydrological cycle. Science, 294, 2119-2124.

Ramanathan, V., Crutzen, P. J., Lelieveld, J., Mitra, A. P., et al. (2001b). Indian Ocean Experiment: An integrated analysis of the climate forcing and effects of the great Indo-Asian haze, Journal Geophysical Reseach, 106(D22): 28, 378-28, 398.

Rotstayn, L. D., Ryan, B. F., \& Penner, J. E. (2000). Precipitation changes in a GCM resulting from the indirect effects of anthropogenic aerosols. Geophysical Research Letters, 27, 3045-3048.

Russell, P. B., Livingston, J. M., Hignett, P., Kinne, S., Wong, J., Chien, A., Bergstrom, R., Durkee, P., \& Hobbs, P. V. (1999). Aerosol induced radiative flux changes off the United States mid-Atlantic coast: Comparison of values calculated from sun photometer and in situ data with those measured by air borne pyranometers. Journal of Geophysical Research, 104, 2289-2308. https://doi.org/10.1029/ 1998JD200025

Şahin, Ü. A. (2020). The effects of COVID-19 measures on air pollutant concentrations at urban and traffic sites in Istanbul. Aerosol Air Qual. Res., 20, 1874-1885. https://doi. org/10.4209/aaqr.2020.05.0239

Satheesh, S. K., \& Ramanathan, V. (2000). Large differences in tropical aerosol forcing at the top of the atmosphere and Earth's surface. Nature, 405, 60-63.

Satya, P., Mrinalini, G., Imran Khanm, Y. D., Sunil, N. (2021). Environmental impact of COVID-19 led lockdown: A satellite data-based assessment of air quality in Indian megacities. Urban Climate 38: 100900, ISSN 2212-0955, https://doi.org/10.1016/j.uclim.2021.100900.

Sayer, A. M., Hsu, N. C., Lee, J., Kim, W. V., \& Dutcher, S. T. (2019). Validation, stability, and consistency of MODIS Collection 6.1 and VIIRS Version 1 Deep Blue aerosol data over land. Journal of the Geological Society Australia, 124, 4658-4688. https://doi.org/10.1029/2018JD029598 
Sehwartz, S. E., Arnold, F., Blanchet, J. P., Durkee, P. A., Hofmann, D. J., Hoppel, W. A., King, M. D., Lace, A. A., Nakajima, T., Ogren, J. A., Toon, O. B., Wizndisc, M. (1995). Group Report: Connections between aerosol properties and forcing of climate. John Wiley, Hoboken, N. J:251-280.

Sharma, S., Zhang, M., Anshika Gao, J., Zhang, H., Kota, S. H. (2020). Effect of restricted emissions during COVID-19 on air quality in India. Science of the Total Environment 728: 138878.

Shi, H., Han, X., Jiang, N., Cao, Y., Alwalid, O., Gu, J., Fan, Y., \& Zheng, C. (2020). Radiological findings from 81 patients with COVID-19 pneumonia in Wuhan, China: A descriptive study. The Lancet Infectious Diseases, 20(4), 425-434. https://doi.org/10.1016/S1473-3099(20)30086-4

Soni, P. (2021). Effects of COVID-19 lockdown phases in India. Environment, Development and Sustainability, 23, 1204412055. https://doi.org/10.1007/s10668-020-01156-4

Srivastava, A. K., Tripathi, S. N., Dey, S., Kanawade, V. P., \& Tiwari, S. (2012). Inferring aerosol types over the IndoGangetic Basin from ground based sunphotometer measurements. Atmospheric Research, 109-110, 64-75.

Suresh, A., Chauhan, D., Othmani, A., Bhadauria, N., Aswin, S., Jose, J., Mejjad, N. (2020). Diagnostic comparison of changes in air quality over China before and during the COVID-19 Pandemic. https://doi.org/10.21203/rs.3.rs30482/v1

Tobias, A., Carnerero, C., Reche, C., Massagué, J., Via, M., Minguillon, M. C., Alastuey, A., \& Querol, X. (2020). Changes in air quality during the lockdown in Barcelona (Spain) one month into the SARS-CoV-2 epidemic. Science of the Total Environment, 726, 138540. https://doi. org/10.1016/j.scitotenv.2020.138540
Vasudevan, M., Natarajan, N., Selvi, S. M., et al. (2021). Correlating the trends of COVID-19 spread and air quality during lockdowns in Tier-I and Tier-II cities of Indialessons learnt and futuristic strategies. Environmental Science and Pollution Research. https://doi.org/10.1007/ s11356-021-16028-1

Wan, S., Cui, K., Wang, Y. F., Wu, J. L., Huang, W. S., Xu, K., \& Zhang, J. (2020). Impact of the COVID19 event on trip intensity and air quality in southern China. Aerosol Air Qual. Res., 20, 1727-1747. https://doi.org/10.4209/aaqr. 2020.07.0364

World Health Organization, (2020). Coronavirus disease (covid2019) situation reports.https://www.covid19. who.int

Zalakeviciute, R., Vasquez, R., Bayas, D., Buenano, A., Mejia, D., Zegarra, R., Diaz, A., \& Lamb, B. (2020). Drastic improvements in air quality in Ecuador during the COVID19 outbreak. Aerosol Air Qual. Res., 20, 1783-1792. https://doi.org/10.4209/aaqr.2020.05.0254

Zambrano-monserrate, M. A., Alejandra, M., Sanchez-alcalde, L. (2020). Science of the total environment indirect effects of COVID-19 on the environment. Science of the Total Environment 728:138813.

Zhang, J., Cui, K., Wang, Y. F., Wu, J. L., Huang, W. S., Wan, $\mathrm{S}$., $\mathrm{Xu}, \mathrm{K}$. (2020). Temporal variations in the air quality index and the impact of the COVID-19 event on air quality in Western China. Aerosol Air Qual. Res. 20:15521568.https://doi.org/10.4209/aaqr.2020.06.0297

Publisher's Note Springer Nature remains neutral with regard to jurisdictional claims in published maps and institutional affiliations. 